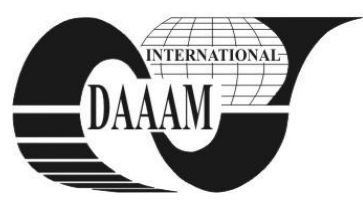

Annals of DAAAM for 2011 \& Proceedings of the 22nd International DAAAM Symposium, Volume 22, No. 1, ISSN 1726-9679 ISBN 978-3-901509-83-4, Editor B. Katalinic, Published by DAAAM International, Vienna, Austria, EU, 2011 Make Harmony between Technology and Nature, and Your Mind will Fly Free as a Bird Annals \& Proceedings of DAAAM International 2011

\title{
IMPACT OF THE ECONOMIC CRISIS OVER THE ROMANIAN HOTEL INDUSTRY
}

\author{
SZTRUTEN LEFTER, G[ina] G[ilet]; DRIDEA STANESCU, C[atrinel] R[aluca] \& MURGOCI, C[ristiana] \\ S[tefania]
}

\begin{abstract}
Starting from the world financial crisis, there has been noticed a deep negative impact on the Romanian hotel industry over the years 2009-2010. Therefore, the Romanian tourism confronts itself with a great challenge in diminishing its impact at macroeconomic and microeconomic level. This paper tries to realise an empirical analysis of the Romanian hotel market following a series of economic indicator, like turnover, occupancy rate, market rate; relevant indicators for providing the proper strategies for economic recovery

Key words: tourism, crisis, hotel industry, Romanian market, trends
\end{abstract}

\section{INTRODUCTION}

The management models applied in the hotel industry worldwide have represented a real example for the local firms. The trends regarding the global industry, the performing and environment friendly hotel units, the employees and the local communities, have determined the necessity of Romanian tourism to correspond to these. More than that, the association with integrated hotel chains, involves the alignment to new international standards, including the environment ones.

\section{INTERNATIONAL TRENDS}

It is easy to understand that the international development of hotel industry represents a consequence of the tourism growth, to international trade and services. It is expected that tourism in the Asia-Pacific continues to obtain the same dynamics as it has in the last years. Some resorts are planning for development in Indonesia, Malaysia, Thailand and Vietnam. More than that, there are important opportunities for of the hotel industry in Eastern Europe, Russia and other countries from the former Soviet Union, were important hotel groups are planning the reorientation of the growth strategies, by new constructions or by new acquisitions. In Asia, the increase of Hong Kong's popularity has been encouraged by the economic boom of South East and also by the taxation system.

Important hotel corporations have established their headquarters in Honk Kong due to the friendly regime of taxation, among these been the group: Mandarin Oriental, Peninsula, Shangri-La etc. In the countries in development, the hotel industry has important increasing perspectives based on political stability, as a component of social and economic progress; such an example was Romania, among other countries from the former communist block that offer expansion strategies for hotel corporations.

The tourism industry is a perspective segment, for which is necessary to attract important investment, for the infrastructure development, and for generating new opportunities for the tourism industry. In other words through unified efforts, tourism can remain one of the main segments of national economies and, at the same time, the most powerful motor of action for all its components.

\section{THE IMPACT ON ROMANIAN HOTEL MARKET}

The Romanian hotel industry efforts, to be in harmony with the modern tendencies of the hotel management are sustained, first by the implementation of modern management techniques (strategic, by objectives, by budgets, leadership, etc.), but also by adopting the newest concepts of hotels like boutique, green hotels, ice hotels, etc.

Unfortunately, at national level, the classic, traditional hotel management techniques are dominant. The modern organization have materialized only in the large cities of Romania, especially in Bucharest, as the classical exploitation is active in an overwhelming proportion (over 90\%) on the spa resorts and on the Romanian sea side resorts (with the exception of the Mamaia resort) .

The concentration of tourism circulation in different periods of time (weekend, summer season) or in different touristic areas (like Valea Prahovei) generates the overcrowding, creating negative pressure over natural and anthropic resources, therefore determining the attempt to adapt the modern management methods to a more responsible policy.

Attracting the well known hotel brands, especially in Bucharest, but also in the urban centres of the country, has influenced in a positive way the top positioning of cities regarding the tourism accommodation capacity.

It can be appreciated that, in general, Romania joins the European trends and evolutions, specific for adequate infrastructure, for a general trend of enlarging the tourism accommodation capacity, for improving the comfort and territorial distribution.

The recovery of business tourism, the increase of budget and small hotels (there aren't probabilities to open huge hotel units), the accent on tailor made services, the world capitals the most favourites markets in 2011in the matter of the development of the hotel industry, large marketing expenses, rebrands, strong methods to reduce the expenses, with the great challenge of not affecting the quality of services are just a few of the industry trends for 2011. The main challenge for the hotel management also represents in 2011, the investors' lack of confidence in the hotel industry, more cautious attitudes from bank. The innovation represents another important aspect in the hospitality industry.

The economic crisis has taken the toll on the activity of Romanian hotel companies. Business of top 50 hotel companies in Romania fell by over $17 \%$ in 2009 . Thus, there was declines from3.56 billion to 2.95billionlei, after many hotels had to close whole floors. Also, there are companies that have registered grow thin 2009, such as Sind Romania Hotel Company which grew by $4.3 \%$ in reaching almost 109 million lei.

Grand Hotels Corporations Society which manages the Marriott Hotel in Bucharest that recorded a turnoverof109.3 million lei, decreasing by $21.7 \%$. In 2009 , Ana Hotels had sales of 107.4 million lei, which is $15.6 \%$ higher than in 2008 . Bucharest Tourism, the company that owns the Radisson hotel 
in Bucharest, registered growth of $73 \%$, from 57 millionto 99million.ContinentalHotelsin 2009 had a turnover of 81.4 million lei, $16 \%$ lower than in 2009.

Sales of World Trade Centre Bucharest, which manages the Hotel Pullman, fell from 55.5 million to 46 million lei (17.1\%). Turnover of the Intercontinental Romania hotel company, which manages the hotel with the same name in Bucharest, fell $22 \%$ last year, from 50.7 million to 39.5 million lei. Average revenue per room of hotels in Bucharest fell by $38 \%$ to about 40 euros/night, once in 2008 reached over 60 euros. The average accommodation fee also fell by $27 \%$, from 120 euros to just over 80 euros. Employment and the number of arrivals and overnight stays in hotels in Bucharest fell from the level of 2008. Hotel market was severely impaired on the operational efficiency. .Strong competition between hotels was reflected by lower rates, special packages to attract more customers, increase occupancy and profitability threshold [CBRE report, 2010]. Hotel market in Romania has decreased by $15-20 \%$ in 2010 and 2011 will not bring are cover, hotels fees are becoming lower and lower.

More over, largely negotiated rates with Romanian hotels by tour operators for travel packages in 2011 are similar to those of 2010, and in some case seven a decreases was recorded.

Hoteliers have been forced to reduce prices because of low purchasing power due to the economic crisis.

Travel agencies often state that discounts and special offers saved domestic tourism in 2010 and have decided to keep the offers also in 2011, a year that promises to be even harder than 2010 in terms of sales packages due to decreases of salaries in public sector. 2010 decreased less than the market average for hostels and spas, while tourist accommodation structures of Bucharest market declined more than the market average, exceeding $20 \%$.

In Bucharest, 4 and 5 star hotels developed good business during this period. There were units that had a very good occupancy rate, high rate even for a boom period, of over $70 \%$. However, hotel market in the capital was pulled down by cheaper housing units. Hotel businesses that declined particularly were built with out professional landmarks by people who do not have experience in this area.

Tourism business grow thon the Bucharest market would be sustainable only if the local economic environment stabilizes.

Regarding new investments in hotels, they are stalled. While major brands such as Marriott and Hilton International have announced several times over the past two years plans to expand the local market, the new units linked to these brands still wait to be seen.

In the capital hotel market there are just a few hotel sunder construction, so by mid-2011 there will be fewer projects to join international chains. Most projects announced in 2007and 2008are now frozen, so the big hotel companies do not have too many options on the market today.[www.dailybusiness.com].

Hotel business requires a considerable infusion of capital, which so far as come largely from bank loans. Niche projects are most appropriate at this time. Two and threes tar hotels would be a safe investment, because in times of crisis, are the most popular for business tourists, and those of leisure. Regarding the four and five stares establishments, Bucharest is not deficient, but in the province these two segments are only in the beginning. For the next few years, Brasov, Bacau and Timisoara offer many opportunities. The fact that occupancy of housing units fell sharply is indeed a problem that investors take into account when designing a hotel. To remain profitable, a four-star accommodation must maintain a minimum occupancy rate of $42 \%-45 \%$ [www.adevarul.ro].

In two-star facilities, this index may fall to $35 \%$. 80,000 euro is the investment in a four star hotel room and35\%isthe minimum occupancy rate to maintain profitability.
Starting from the idea that Bucharest tis not a holiday destination, all Bucharest hotels records have huge differences between weekdays and weekends occupancy. Demand for holidays in Bucharest is still very limited, and short-term perspectives do not expect a huge change [www.dailybusiness.com].

The development and modernization of Romanian tourism, has been accompanied, as it should be, by important hotel transformations; it is about the increase of the number of hotel units, in the present being over 5000, by the typological diversification of those, the space distribution, the services offered.

\begin{tabular}{|c|c|c|c|c|}
\hline Years & \multicolumn{2}{|c|}{ Number of units } & \multicolumn{2}{c|}{$\begin{array}{c}\text { Number of existing } \\
\text { places }\end{array}$} \\
\cline { 2 - 5 } & $(\mathbf{y n})$ & $\left(\mathbf{y n} / \mathbf{y}_{\mathbf{0}}\right)$ & $(\mathbf{y n})$ & $\left(\mathbf{y n} \mathbf{y}_{\mathbf{0}}\right.$ ) \\
\hline 2004 & 3900 & 100,0 & 275941 & 100,0 \\
\hline 2005 & 4226 & 108,3 & 282661 & 102,4 \\
\hline 2006 & 4710 & 120,7 & 287158 & 104,0 \\
\hline 2007 & 4694 & 120,3 & 283701 & 102,8 \\
\hline 2008 & 4840 & 124,1 & 294210 & 106,6 \\
\hline 2009 & 5095 & 130,6 & 303486 & 109,9 \\
\hline 2010 & 5279 & 135,3 & 311.698 & 112,9 \\
\hline
\end{tabular}

Tab.1. Indicators of tourist accommodation infrastructure in Romania

In regard to the number of units, it has grown, in 2010, with approximately $35 \%$, and the number of existing places with $12 \%$, compared to the year 2004 , as shown (Tab.1). This spectacular development ( $1 / 3$ from the total), has been influenced by the development of the business hotel segment, the Eastern Europe becoming an important market for large hotel chains; therefore, in connection with the investment fund, the number of units has grown constantly, in spite of the difficulties generates by the economic crisis.

\section{CONCLUSIONS}

Regardless of the form of tourism, tourist destination, chosen hotel, product consumed, the services provided by the reception structures are closely related to natural resources and how the yare exploited. In conclusion, the Romanian tourism potential is great thanks to many natural recovery alternatives and cheap labor. The initiatives undertaken by local hotel chains and the governmental legislative support and the promotional one and a good collaboration with the local authorities will represent a real help to the Romanian hotel business field.

\section{REFERENCES}

Holden A., In Need of New environmental Ethics for Tourism, Annals of Tourism Research 30, Elsevier Ltd.UK., (ISI Journal), 2003Lefter(Sztruten) G.G

Oprescu A.E., Gheorghe C.M. Sebea M., Regional Cooperation and its role in declining the impact of world crisis over tourism activity in Romania, Annals of DAAAM for 2009\&ISI Proceedings of the 20th International DAAAM Symposium, 2009

Minho Cho, Key factors for a successful cooperation between SME's and global players in hotel industry, International Journal of Contemporary Hospitality Management, vol.9, no.5/6, Emerald Group Publishing Limited, 2005

CBRE report, quoted by Financial

*** (2011) www.dailybusiness.ro Accessed on 15/08/2011

*** (2011) www.regim-hotelier.com/ Accessed on 15/08/2011

*** (2011) www.adevarul.ro Accessed on 15/08/2011 